\title{
A Quest for The Self: Conceptual Metaphor in Slave
}

\section{Amal Ahmed Eassa Gami}

\author{
Suez University
}

\begin{abstract}
This study analyzes the conceptualization of slavery and freedom in slave narratives. More precisely, it investigates the different conceptual metaphors regarding slavery versus freedom as used by Mende Nazer in Slave. The study also investigates the different autobiographical memory forms as a psychological necessity during autobiographical memory retrieval as well as the notion of social death as an aspect of slavery and their relation to conceptual metaphor. Finally, the study aims at identifying the total selfconcept and the associated attributes as unconsciously revealed through the use of CM. It has been found that both FREEDOM AND SLAVERY are conceptualized in terms of JOURNEYS. Nonetheless, the difference between both journeys is that the FREEDOM JOURNEY turns out to be a PSYCHOLOGICAL JOURNEY in which Mende conceptualizes only through imagination. Moreover, it has been concluded that there is a strong tie between conceptual metaphor and autobiographical memory in slave narratives. Additionally, the notion of social death is embedded within the unconscious use of conceptual metaphors in slave narratives. Finally, it has been concluded that the intersection of all three theories; namely, conceptual metaphor, autobiographical memory and social death, helps in the construction of the protagonist's self-concept.
\end{abstract}

Keywords: slave narrative, conceptual metaphor, autobiographical memory, social death, self-concept

The present study aims at studying the conceptual metaphors of freedom and slavery themes as used by Mende Nazer, the protagonist of Mende Nazer and Damien Lewis' Slave 2003 when writing about her slavery. This requires memory retrieval as a cognitive process for remembering certain events that have taken place previously at some point in the protagonist's life. Conceptual metaphors (CMs) are pervasive not just in language but also in thought (Lakoff and Johnson, 1980, 2003). Accordingly, conceptual metaphors reflect what users of a language think of themselves, other people and even the external world in the most conventional way. Thus, from a cognitive-linguistic viewpoint, the study aims at examining how ex-slaves conceptualize and think about abstract concepts in terms of concrete ones during autobiographical memory retrieval. In other words, it studies the relationship between the conceptual metaphors as used by the protagonists in slave narratives and autobiographical memory. Besides, from a cognitive psychology perspective, "[A]utobiographical memory is about the self... [it] is the source of information about our lives, from which we are likely to make 
judgments about our own personalities and predictions of our own and, to some extent, others' behavior" (Rubin, 1986, p. 7). As a result, the study also aims at studying what can be revealed about the conceptualizations of The Self of ex-slave females through studying conceptual metaphors that are related to autobiographical memory. Another important factor of this study is the notion of 'social death' and its relation to slavery. Patterson (1982) defines a slave as a "socially dead person. Alienated from all "rights" or claims of birth, he ceased to belong in his own right to any legitimate social order. All slaves experienced, at the very least, a secular excommunication"(p.4). As included in the very definition of a slave that she/he is socially dead, one of the aims of the study is to see whether the notion of social death is to be detected in the unconscious use of conceptual metaphors.

It is observed, thus, that the key concepts in the present study are in someway or another related. Intersecting with one another, they provide the research with rich and comprehensive understanding of the main problem investigated; hence, they enrich the findings concluded.

First, both conceptual metaphor (CM) as the cognitive linguistic variable and autobiographical memory (AM) as a psychological variable belong to the unconscious mind. Intersecting with one another, they help in constructing the self-concept of each of the protagonists as hidden beneath the level of cognitive awareness. Operating at the conceptual level (Lakoff and Johnson, 1980, 1999, 2003; Evans and Green, 2006; Kövecses, 2010), both CM and memory belong to the "cognitive unconscious" (Lakoff and Johnson, 1999, p.3). Defined as "the scientific discipline that studies conceptual systems," cognitive science discovers that "most of our thought is unconscious [as] it operates beneath the level of cognitive awareness, inaccessible to consciousness and operating too quickly to be focused on"(p.3). Moreover, "memory" (Lakoff and Johnson, 1999, p.3) as well as all aspects of thought and language including "metaphorical thought" (Lakoff and Johnson, 1980, p.272) belong to this cognitive unconscious. The importance of such cognitive unconscious, Lakoff and Johnson (1999) claim, comes from the fact that it is responsible for our conscious thought. Additionally, they claim that the cognitive unconscious functions as a "hidden hand" that allows us to conceptualize all aspects of our experiences. Therefore, studying CM as produced unconsciously through memory retrieval allows the researcher to delve deeply in the protagonists' minds uncovering hidden thoughts, beliefs and convictions about themselves, the other and the world as a whole. 
Second, slave narrative as a form of autobiography (Olney, 1985) is engaged in memory retrieval acts or, to be more precisely, a selective autobiographical remembering. According to Olney (1985), the role of memory in autobiographical writing is that

it creates the significance of events in discovering the pattern into which those events fall ... such a pattern will be a teleological one bringing us, in and through narration ... to the present ... It is in the interplay of past and present ... that events are lifted out of time to be re-situated not in mere chronological sequence but in patterned significance. (p.149)

Olney's (1985) words suggest that narrators of slave narratives pick out from their past experience the "significance" of events and organize them in a pattern that moves the reader to their present state. Thus, working selectively in a narrative (Ruth and Vilkko, 1996), memory plays an important role in narration in that it creates a pattern of events in which it is differentiated from a mere chronological order as in historical writings.

Third, slave narrative as a form of autobiography is closely related to the terms "self," "identities" and "self-concept. According to Smith and Watson (2005), autobiographical narrators in slave narratives don't merely tell stories that "come" from a life, instead, they "rework and improvise ... to compose identities" (p.357). In other words, narrators in slave narratives are engaged in "performative" autobiographical telling in which they enact the ""self" that it claims has given rise to the "I". This "I", Smith and Watson (2005) claim, is not a unified, stable construct' rather, it is "fragmented, provisional, a sign with multiple referents". Those multiple referents "make diverse calls to identity" through narration. And as defined as "an organization of identities"(Gecas, 1982:24), the "self-concept" is comprised of the multiple identities represented by the "I" in autobiographical narration.

Fourth, slavery as a system is strongly tied to the notion of social death which represents the social variable of the study. Because a slave is defined as a "socially dead person" (Patterson, 1982, p.38), Králová (2015) claims that the concept of "social death" is to be applied to the notion of "slavery"(p.235). Again, intersecting with CM and AM they help in uncovering how Mende Nazer, an ex-slave girl, unconsciously sees herself from a social viewpoint; hence, the emerging self-concept. Adding a social variable to the study of slave narratives from a cognitive linguistic viewpoint enriches the research as well as the findings concluded. Within social sciences, being a slave is being a socially dead person (Patterson, 1982). And delving into the unconscious mind of those protagonists as being ex-slaves without accounting for their view of themselves as slaves, hence, socially dead, would be fragmented. 
Accordingly, studying CMs within the retrieval of autobiographical memory of ex-slave narrators is a multidimensional, interrelated study.

The Corpus of the present study includes Mende Nazer and Damien Lewis' Slave: My True Story 2003. It tells the story of a young Sudanese girl who was sold into modern domestic slavery (Slave, 2015). There are two main reasons behind corpus selection. First, it has been international bestseller narrative and has received quite good praise and criticism. For example, it was mentioned in The Washington Post that Slave is "[B]eautiful and at times heart-wrenching" (Slave, 2015). Additionally, Monica Ali, the author of Brick Lane and who is "named in Granta's 20 Best British novelists 2003" (Arikan \& Koçsay, 2010, p. 491), states that "Slave constitutes an act of tremendous courage" (Slave, 2015). Second, the victim of Slave is a Muslim Arab young girl. Found almost in every country (McGough, 2013, p. 26), modern slavery is extensively found in different Muslim Arab countries. According to Murphy (2014), many slave narratives are written by people who were enslaved in countries like Sudan, Yemen, Lebanon, Uganda, Cambodia and many others. Thus, such narrative not only sheds light on a shocking, horrible fact of the $21^{\text {st }}$ century which is the existence of contemporary slavery but it also stresses the fact that it does exist in the Muslim Arab world.

Overall, the main aim of the study can be formulated in the following: the study aims at examining and analyzing from a cognitive viewpoint, first, the conceptual metaphors of slavery versus freedom as used by Mende Nazer, the protagonist of Slave. Second, the present study tries to reveal how Mende as an ex-slave female is socially dead as revealed through the unconscious use of the different conceptual metaphors identified. Third, the current study also tries to unfold the complex nature of the relationship that holds between conceptual metaphors, autobiographical memory and social death, on the one hand, and the relationship between these three terms and the construction of Mende's self-concept as revealed through language, on the other.

The literature of $\mathrm{CM}$ in narrative discourse reveals that $\mathrm{CM}$ has various functions depending on the kind of the narrative within which it is studied. First, CM is studied within fiction narrative such as novels. For instance, some researchers study $\mathrm{CMs}$ in fictional narrative as textgenerating devices and as tools for revealing the writer's hidden views (Talmantaitö, 2008). Other researchers study nonverbal CMs in narrative and its influence on meaning interpretation (Schirrmacher, 2017). Other researchers compare between the use of conceptual metaphors in linguistic and nonverbal visual narrative structures and conclude that both 
modes of metaphors have "significant message and a cultural value to convey"(Seddeek and Ehsan (2017, p.118). Moreover, some researchers study the role of $\mathrm{CM}$ in conveying the protagonist's feelings and future actions (Kurniawati et al., 2014), revealing the historical-cultural settings embedded in narrative (Walker, 2013; Singh, 2010; Yamina, 2016) as well as in interpreting social behavior and communication (Soloshenko, 2016). Besides, other researchers study CM of the Self in fictional narrative as a tool for revealing and reflecting the truth about human beings (Hernández, 1997). Second, CM is also studied in non-fiction narrative in which they adopt different functions. For example Martens and Biebuyck (2013) study CM for cancer in disease biographies. Nonetheless, the literature of conceptual metaphors almost lacks studies that are concerned with studying conceptual metaphors in autobiographies, specifically in slave narratives; the main concern of the present study. However, Norman (1993) studies how Frederick Douglass in his autobiography "recreates a historical self and the collective spirit of the race by knowing the ... metaphors that express his deepest sentiments about his freedom, the freedom of black people, the horrors of slavery and enlightenment" (P. 22). Moreover, Friend (2012) studies CMs in the spiritual autobiographies of Teresa of Avila (1515-1582) and Sarah Edwards (1710-1758). Friend (2012) concludes that both Teresa and Sarah Edwards can approach the full dimensions of their spiritual experiences of God through the use of CM. Additionally, there are few researchers who study metaphors of the Self in autobiographical writings. For example, Li (2011) studies spatial metaphors for the Self in Chinese autobiographies based on the Lakoff and Johnson's (1999) bifurcation of a person into a Subject and a Self. Furthermore, CM is studied as well in other narrative forms: in health practice (Arvay et al., 1999; Tally, 2016), in narrative scientific discourse (Leslie, 2012), in migrants' narrative discourse (Golden and Lanza, 2013), and in the narrative embedded in videogames (Kromhout and Charles, 2013)

As presented in the review of literature, there are a few shortcomings concerning the research on $\mathrm{CM}$ and its relation with the main issues addressed in the study at hand. First, although there is an extensive body of research that focuses on examining CM in different areas of study, there are few studies that focus on investigating CM in autobiography as non-fictional narrative. Second, the studies that tackle $\mathrm{CM}$ and the Self focus only on the folk theory of the bifurcation of a person. Nevertheless, there are other Self distinctions that are neglected by most researchers including the one adopted in the present study which deals with the Self as a component of memory. Third, the literature review also lacks studies that relate the phenomenon of slavery and its 
social consequences on its victims such as the notion of social death with $\mathrm{CM}$ as a cognitive linguistic variable represented in the slaves' language when telling or writing about their experience. Fourth, it is also observed that researchers neglect a psychological necessity when investigating CM in non-fiction narratives. More precisely, researchers studying $\mathrm{CM}$ in autobiographies marginalize the role of autobiographical memory retrieval as it is necessary for recalling one's past.

The significance of the current study lies in three main factors. Firstly, studying CM -- a "natural outcome of human mind" (Gibbs, 2008, p.4) -- in slave narrative helps in revealing the protagonist's unconscious mind; hence, uncovering her self-concept. Secondly, according to Ruth and Vilkko (1996), the narrator in autobiographies is "free to choose what to present and what to conceal in accounts of life" (p. 168). This means that there are certain episodes that may be omitted from the life story, while others may be given more prominence and; thus, may be repeated. Thus, the importance of studying autobiographical memory lies in that it shows what ex-slave victims include in their autobiographical memories and how what they select to narrate about their past unconsciously relates to their use of conceptual metaphors. Finally, the literature review lacks studies that focus on examining the relationship between autobiographical memory, conceptual metaphors and slave narratives. More specifically, the present study helps in filling the gap with the answer to the following question: what functions do conceptual metaphors have in slave narratives?

The theoretical framework of the current study includes four main theories. The first is Conceptual Metaphor Theory (CMT) (Lakoff and Johnson, 1980; 1999; 2003). CMT is launched by Lakoff and Johnson (1980) in which metaphor is modeled as a mapping from a conceptual source domain to a conceptual target domain. The second is Brewer's (1986) account of Autobiographical Memory. Brewer (1986, p.26) defines autobiographical memory as "memory for information related to the self." There are four types of memory inputs one of which is "egoself" input (Brewer, 1986, p. 29). The ego-self input, according to Brewer (1986), is responsible for the retrieval of four types of autobiographical memory; namely, 1) personal memory (PM), 2) autobiographical fact (AF), 3) generic personal memory (GPM) and 4) self-schema (SC). The third is McConnell \& Strain's 2007 framework of the Self-Concept. They present the Self as comprised of "multiple self-aspects, each of which is comprised of a series of attributes" (p.57). The fourth is the notion of Social Death (Králová, 2015; Patterson, 1982). According to Králová (2015), social death is used "when a person/group has experienced 
extreme and profound loss"(p.236). Králová (2015) argues that the idea of 'losing' in a definition of social death has three facets all of which can be applied to slavery: 1) Loss of Social Identity, 2) Loss of Social Connectedness and 3) Losses Associated with the Disintegration of the Body.

\section{Method and Procedure}

The procedure used for data analysis consists of two main steps. The first is concerned with identifying and analyzing the different CMs of slavery and freedom based on the framework of Conceptual Metaphor Theory as set forth by Lakoff and Johnson (1980, 2003). At the same time, the researcher considers the different forms of autobiographical memory and analyzes them in accordance with the CMs identified. In addition to that, the notion of social death is to be applied through detecting the three facets of social death; namely, loss of social identity, loss of social connectedness and losses associated with the disintegration of the body and relates them to the CM identified. The second is concerned with detecting and identifying the Self-Concept of the protagonist. After identifying the different autobiographical memory forms and relating them to the CMs used, the self-concept of the protagonist is identified using McConnell and Strain's (2007) framework for identifying self-concept content and structure. In so doing, the researcher is able to: 1) identify both the self-aspects and the attributes attached to them, 2) identify how the protagonist sees herself as a slave, and 3 ) determine whether her self-concept reflects her as socially dead.

\section{Data Analysis}

This section analyzes the conceptual metaphors of FREEDOM and SLAVERY themes used by Mende Nazer in Slave. The metaphors included in the analysis are drawn mainly from the source domains of JOURNEY and CONTAINTER and their relation to SLAVERY and FREEDOM target domains. All in all, Mende conceptualizes the period of her life when she becomes a slave to being freed again as A JOURNEY FROM SLAVERY TO FREEDOM. However, it turns out to be not a straightforward, smooth journey nor is it a short one. This not-astraightforward journey is depicted through a process of conceptualizing FREEDOM. First, FREEDOM is conceptualized as a POSSESSED FOOD TREAT or UNIQUE TREASURE when it comes to the idea of not having it; thus, being unaware of or unfamiliar with it. Second, it is conceptualized as A FRIGHTENING/TERRIFYING ENTITY after Mende is freed with the help of some Nuba men in London. Third, it is conceptualized as A WAR in the context of trying to stay in London as an attempt of staying free. Finally, the whole SLAVERY-FREEDOM JOURNEY is conceptualized as A JOURNEY FOR THE SEARCH OF 
THE SELF. This process, however, seems to be based on the principle of familiarity. For instance, being familiar with SLAVERY, Mende always conceptualizes it in terms of A CONTAINER. Likewise, FREEDOM is conceptualized in terms of A CONTAINER whenever it is talked about in terms of being familiar with it.

Slave consists of four parts each revolves around one particular phase in Mende's life. The first part is entitled "My Childhood with the Nuba." The second part is entitled "Into Slavery." The third part is entitled "Journey to Freedom." The fourth part is entitled "Truly Free?" The very titles of the second and the third parts comprise two CMs: SLAVERY IS A CONTAINER and FREEDOM IS A JOURNEY, respectively. "Into Slavery," tells how Mende becomes a slave, what difficulties and problems she faces and how she is treated by her master. It ends with Rahab's decision to send Mende to London to continue her slave services to her sister Hanan. Thus, it seems that Mende is actually heading towards a real journey. Interpreting the title of the third part, it may be clear that Mende unconsciously conceptualizes her journey to London as A JOURNEY TO FREEDOM. Accordingly, FREEDOM is conceptualized as A DESIRED DESTINATION OF A JOURNEY.

Nevertheless, "Into Slavery" comprises a number of JOURNEY metaphors which conceptualize Mende's cognitive ability of remembering her past with her family. This implies that within THE SLAVERY CONTAINER, Mende conceptualizes herself being on other JOURNEYS till she joins her FREEDOM JOURNEY at the end.

\section{REMEMBERING IS TRAVELLING/ THE PAST IS BEHIND}

In the following quote, Mende uses the metaphors REMEMBERING IS TRAVELLING and THE PAST IS BEHIND. Expecting some guests in one evening, Rahab orders Mende to go to hose down the patio at the front of the house. That night, recalls Mende, reminds her of home in the Nuba Mountains because she finds that the hosepipe is spurting water. This seems to remind Mende with that time of the year when it rains. As a result, Mende forgets for a while that she is a slave and starts to sing the rain song:

Are kukure, are kukure dukre-- the rain is coming, too much rain! For a few blissful moments, I was a thousand miles away from the terrible house, back in my village. I was with my friends singing the rain song and we were happy because we knew there would be a good harvest this year. (Nazer \& Lewis, 2003, p.163-164). 
In this example, Mende conceptualizes the cognitive ability of REMEMBERING in terms of TRAVELLING "a thousand miles away" from where she is now in Rahab's house. Moreover, Mende seems to change direction and goes "back" to her desired DESTINATION which is her home "village" comprised in the CM THE PAST IS BEHIND. This implies that Mende is on another JOURNEY: A JOURNEY OF SLAVERY where she is enslaved in Rahab's house and changing direction means that Mende has to go "back." In addition to that, this incident of "spurting water" seems to trigger a Generic Personal Memory (GPM) where Mende gives a visual image of herself and some friends singing happily back in the village when it rains. A GPM implies that it is a repeated experience meaning that whenever it rains, Mende and her friends would engage in a happy time singing and playing with the water; an image which clashes with what happens to her as a slave. However, Mende adopts an Observer Perspective (O) perspective in recalling that memory. In so doing, she adopts the position of an onlooker; thus, she is "seeing" herself with her friends spending a happy time singing. This GPM presents Mende's inconsistent multiple identities; Mende's past childhood self is different from Mends as a slave. Adopting an observer perspective, Mende is conceptualized as standing in the threshold of "the happy time" of her childhood where she is seeing herself from the "outside." This implies that Mende's narrated "I" is different from the child version of her Self; hence, splitting selves. In other words, adopting an $\mathrm{O}$ perspective in recalling this memory, Mende stresses the fact that her past, happy self is inconsistent with her narrated "I."

Additionally, the metaphor MENDE IS SOCIALLY DEAD is to be inferred from the analysis so far. First, this inconsistency between Mende's younger self and Mende as a slave implies an identity crisis. Being a "different" person from what she has used to be (Libby and Eibach, 2002), implies a Loss of Social Identity. Mende is no longer that happy young girl who used to play with her friends celebrating a rainy season which is good for harvesting. Instead, she has become a young slave girl who happens to "clean down the patio" and who finds that the hosepipe is "spurting water." Second, Mende's use of the CM REMEMBERING IS TRAVELLING implies Loss of Social Connectedness and Losses Associated with the Disintegration of the Body. The metaphor unconsciously reveals the fact that a slave can only feel free and can only enjoy social connectedness inside her/his head. Mende now in her mind can travel a thousand miles back home only through imagination. Loosing her social connectedness with her family and friends, Mende can have normal human relationships only inside her 
mind. Thus, Mende is trapped inside her head having no autonomy over her body. Moreover, as a result of recalling the GPA picturing herself playing and singing happily with her friends, Mende starts to sing out loud "the rain song." But unfortunately, Mende is caught by Rahab who tells her to give the hosepipe back to her:

"Come here!" she barked at me. "And give me that hosepipe ... she snatched it from me and grabbed my arm. And then she started to beat me across the back and shoulders with the hosepipe. She struck me again and again and again and I was crying and pleading for her to stop ... (Nazer \& Lewis, 2003, p. 164).

Accordingly, having TRAVELLED BACK HOME due to a recall of a GPM, Mende seems to be exposed to "naked force;" hence, having no authority over her body.

Subsequently, there are two self-aspects emerging from both the visual image contained in the GPM and the CM. First, Mende's GPM retrieval implies an affective self-aspect of how she feels towards her relationship with her friends before being captured as a slave. Mende unconsciously reveals that she has been happy and free during her childhood before she has been taken as a slave. Second, the metaphor REMEMBERING IS TRAVELLING and the implied metaphor of MENDE IS A SOCIALLY DEAD PERSON result in another self-aspect Mende's self-concept. The following diagram shows this:

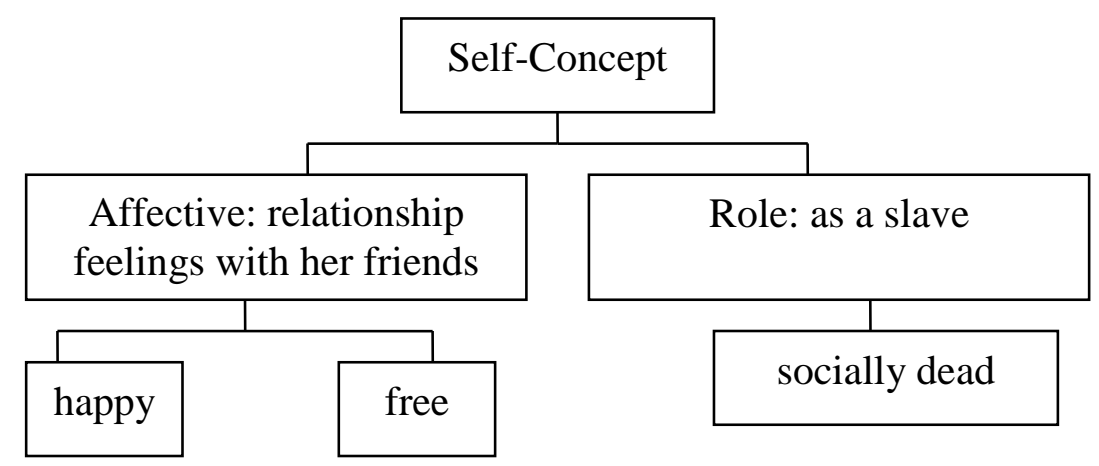

\section{THINKING/REMEMBERING IS A BACKWARD MOVEMENT}

Yet, in another occasion, Mende is engaged in an instance of PM in which she experiences a mental image that corresponds to an episode in her life as a slave while she was in Rahab's house. Preparing for a dinner party in Rahab's house, Mende spends all day in the kitchen cooking "beef and chicken curry with rice and lots of salads" and making "fresh juice." By the time the guests arrive, Mende starts to serve them juice and then dinner. After that, Mende recalls staying in the kitchen to clean up the mess while being interrupted by the guests' children for "the kitchen 
had become the focus of the children's activities" (Nazer \& Lewis, 2003, p. 180-181). As a result, Rahab's youngest daughter Usra falls off the kitchen's table and hurt herself:

... suddenly there was a crash and a scream. I spun around, only to see that ... Usra had fallen off the table and hit her head on the floor. She'd been following Hanin's lead, reaching for her cup. I ran to pick her up and I could see that she had cut her lip ... there was a lot of blood and Usra was wailing loudly ... "What's happened! What's happened?" Rahab asked, as she came rushing in from the patio. (Nazer \& Lewis, 2003, p. 180-181).

Holding Mende responsible for Usra's injury while playing in the kitchen, Rahab beats Mende so hard that she crashes into a sharp edged table. This causes Mende to lose consciousness because of a deep cut on her right leg:

... she punched me so hard that I fell backward and crashed into my little table in the corner. The table was made of metal. As keeled over, one of the sharp edges ripped deep into my leg. I felt a stabbing, searing pain. (Nazer \& Lewis, 2003, p. 180-181)

After that, Rahab takes Mende to the hospital. Mende then recalls another PM with an F perspective where the scene appears from her own position. Coming around again after being unconscious for quite sometime, Mende recalls seeing Rahab being concerned over her health and happy that she is alive. This seems to remind Mende of her mother:

And I was so used to Rahab being cruel to me, without showing a shred of remorse or concern. So why did she now seem so happy that I was alive? I was hurt and she seemed concerned for me. Somehow in my groggy mind, just for a few moments, Rahab reminded me of my mother. (Nazer \& Lewis, 2003, p. 180-181)

Thus, adopting an $\mathrm{F}$ perspective while recalling, Mende is somehow moved by Rahab's sentiments towards her that she is reminded of her own mother. Unfortunately, Mende's conception of Rahab's feelings seems faulty; Rahab's worry and happiness that Mende is alive was not due to any concerns over Mende's health but because "[I]n reality, Rahab didn't want it to be known publicly that she had a slave. And if I had died she would have been responsible for my death" (Nazer \& Lewis, 2003, p.184). And the fact that Mende's MIND IS A GROGGY CONTAINER echoes this misconception of Rahab.

Thus, engaged in two instances of PM where Mende recalls being beaten up brutally by Rahab and then been taken to the hospital seems to trigger another PM in which Mende experiences a mental image that corresponds to an episode from her life in the Nuba Mountains before 
being enslaved. Lying on the hospital's bed still feeling confused and tired, Mende is reminded of another incident back home with her friends and family. While trying to collect some firewood from the forest with her friends, Mende's leg was cut from a big thorn. However, Mende recalls that all her friends and her parents were concerned about her and were so kind to her:

My mind drifted back to a time in the Nuba Mountains when I was still very young. I had gone to fetch firewood from the forest with my friend Kheko and two other girls... But as we set off through the forest ... I felt a searing pain in my foot... there was a big thorn sticking out of the top of my foot. (Nazer \& Lewis, 2003, p.183)

Just as mentioned previously in example 1, Mende is engaged in two instances of JOURNEY CMs in order to juxtapose her life with her parents with her life as a slave. More specifically, adopting a $\mathrm{F}$ perspective while recalling, Mende tries to re-experience her feelings back then with her family and friends. Mende conceptualizes THINKING/REMEMBERING in terms of A BACKWARD MOVEMENT to which she reaches A TIME IN THE NUBA MOUNTAINS which is conceptualized as A DESTINATION. Both metaphors imply that Mende is able to move and go back home only in her MIND. Moreover, THE PAST with her family is her aimed and desired DESTINATION which is also can be reached in her MIND. Adopting a $\mathrm{F}$ perspective, Mende focuses on how she longed for love, affection and real concern over her health:

I remembered lying on the riverbank as dusk began to fall ... I was very glad that Kheko was with me. Finally, I caught sight of my father ... leading my mother ... [who] cradled my head in her lap. I remembered how concerned she looked. She stroked my hair and kissed me and kept repeating to me, softly: "Mende, my little girl, you're going to be all right. Don't worry. Don't worry. I'm here." (Nazer \& Lewis, 2003, p.184)

Recalling how Mende's mother "cradled" her head and how she kissed her as an attempt to make Mende feel unworried implies Mende's craving for the love and care of a mother. This justifies Mende's false conception of Rahab as a substitute for her mother. Therefore, it seems that Mende's JOURNEY OF REMEMBERING IS A PSYCHOLOGICAL JOURNEY to which she reaches a destination where she finds love, affection, care and kindness. 
Moreover, the metaphor MENDE IS SOCIALLY DEAD can be inferred from both the PMs recalled as well as the metaphor THINKING/REMEMBERING IS A BACKWARD MOVEMENT. First, the PM concerned with Mende getting beaten by Rahab with the use of "the hosepipe" implies Losses Associated with the Disintegration of the Body in which Mende loses control over her body. Second, recalling being taken to the hospital and having a misconception of Rahab as a "substitute" of her mother "in" her "groggy mind" reflects Mende's Loss of Social Connectedness. Losing her role as a daughter in a family and thus losing the sense of family, Mende deep inside wanted Rahab to adopt the role of her mother. But unfortunately "Rahab was a poor substitute for a mother... But I had no one else" (Nazer \& Lewis, 2003, p.184). Third, the metaphors THINKING/REMEMBERING IS A BACKWARD MOVEMENT and A TIME IN THE NUBA MOUNTAINS IS A DESTINATION also imply the metaphor MENDE IS SOCIALLY DEAD. These metaphors suggest that Mende can only feel free inside her head. In other words, having no control over her own body, Mende only feels free inside her mind.

Thereupon, three of Mende's self-aspects are to be detected from the analysis of the CMs and the PMs identified. First, Mende's PMs retrieval of the beating and the hospital episodes as juxtaposed with the PM of the incident of "a time in the Nuba Mountains" show that she conceptualizes herself with her family and friends as a lovable, worthyof-care-and-kindness person as opposed to conceptualizing herself with her master as invaluable and unworthy-of-care-and-kindness person. Second, the CM identified within this context implies that Mende conceptualizes her role as a slave as being socially dead:

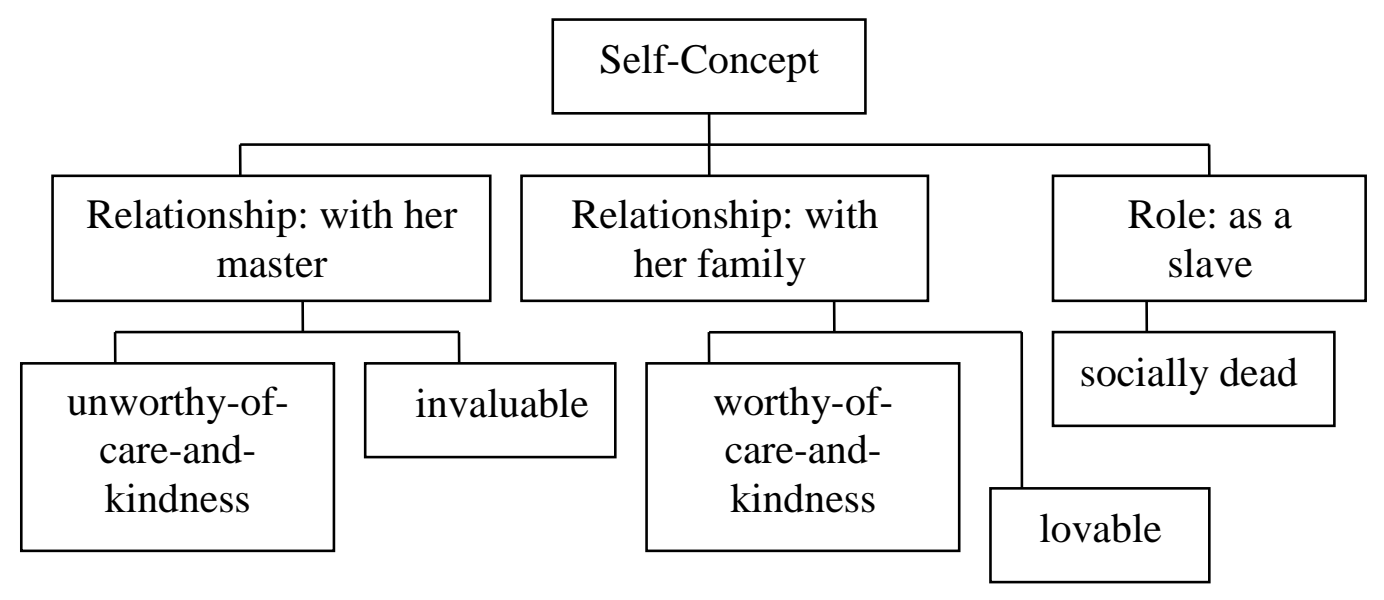




\section{REMEMBERING IS A BACKWARD MOVEMENT/ THE MIND IS} AN OBJECT BEING THROWN IN A PLACE

As moving forward with the narrative, Rahab sends Mende to her sister Hanan in London to be her slave. Mende recalls getting outside the house one day to throw the trash in the bin on the driveway. Then, she notices a big crowd out on the street which happens to be a wedding where people are dancing and singing. And for about "five minutes" Mende feels happy again. Unfortunately, Hanan catches her "out" then she gets mad: Hanan for the first time since Mende's arrival to London 1) calls her "yebit," just like Rahab and 2) locks the door of the house from the inside so that Mende can't ever get outside again.

This incident seems to trigger an instant of SC. Realizing that she is never going to be free again; hence not being able to achieve her dreams, Mende recalls a SC in which she presents her ideal self as she has always wished to become a doctor when she was a child. Within the SC Mende uses another instance of the metaphor REMEMBERING IS A BACKWARD MOVEMENT with THE MIND is conceptualized in terms of AN OBJECT BEING THROWN IN A PLACE:

I cast my mind back to my earliest ambitions in life, my dream to become a doctor, after we had taken my brother Babo to the hospital in Dilling and he had nearly died of dysentery. This had convinced me that we needed a doctor in our village ... I remembered talking to my father about my dream of becoming a doctor, and the way he had promised to support me in any way he could. The very thought of those happy, happy times brought tears to my eyes. (Nazer \& Lewis, 2003, p.277)

This image metaphor echoes how Mende only feels free through remembering her past life with her family before she has been captured as a slave. After being caught outside of Hanan's house, Mende now knows it too well that there is "no way out of [her] present situation." As a result, she starts "living in the happiness of [her] past" (p.276). In so doing, Mende travels "back" in time to moments with her family where she feels their "closeness and affection." Thus, it is A VIRTUAL JOURNEY that Mende makes inside her MIND in order to be able to taste freedom again. Mende, instead of continuing with her SLAVERY JOURNEY, changes her destination and travels "back" in time. Such mind movement implies that she is only free inside her mind: it's the only way Mende can ever feel free again. Again, it seems that Mende's JOURNEY OF REMEMBERING turns out to be A PSYCHOLOGICAL JOURNEY OF FEELING HAPPY AND FREE. 
Nevertheless, Mende's self-schema of having used to identify herself with becoming a doctor constitutes a powerful aspect of her Self. Actually, Mende specifies a whole chapter entitled "My Dream" within the first part of Slave entitled "My Childhood with the Nuba" for presenting how and why she had decided to become a doctor in the first place. And the possessive pronoun "My" stresses this very idea. It implies that it used to be 'her dream' to become a doctor. Mende recalls that one day her favorite brother Babo became seriously ill and was sent to the hospital in Dilling because of the lack of any proper medical facilities in her home village:

One day, my brother had become very ill. He had a terrible pain in his stomach and he could only urinate blood and mucus. There was no proper medical doctor in our village. The only option was to go to the Kujur -- our shaman or traditional medical man -- or try to heal Babo at home. (Nazer \& Lewis, 2003, p.84)

From that moment on, Mende decides she has to become a doctor to be able to treat her beloved ones in the village and to save them from being taken to Dilling, the nearest big town. As a result, Mende's self-schema of becoming a doctor helped her to modify her behavior at school:

That's when I first thought about becoming a doctor myself, and immediately redoubled my efforts at school ... I kept talking to my father about becoming a doctor. I would need all of his support if I was to stand any chance of achieving my dream. I knew it would be a long road that I would have to travel. (Nazer \& Lewis, 2003, p.89)

Within this SC, Mende conceptualizes her ACADEMIC EXCELLENCE in terms of A JOURNEY and that HER EFFORTS TO STUDY HARD AND DO WELL AT SCHOOL in terms of TRAVELING THROUGH A LONG ROAD with HER DREAM OF BECOMING A DOCTOR is conceptualized as THE DESTINATION. Ironically, such JOURNEY clashes with the JOURNEY in which Mende unconsciously chooses to make in order to go "back" to her dream of becoming a doctor; The reason Mende recalls the SC in Hanan's house after being caught is because she realizes that this dream will never be achieved.

Additionally, the metaphor MENDE IS SOCIALLY DEAD can be inferred from the SC and the CM analysis. First, recalling an instance of SC in which Mende remembers how she used to identify herself with becoming a doctor and then realizing that this won't ever become true implies that Mende loses an aspect of her Self. Now after being caught outside and realizing that she is going to be stuck forever inside Hanan's house, Mende unconsciously reveals A Loss of Social Identity. Therefore, 
having lost a powerful aspect of her identity, Mende unconsciously conceptualizes herself as A SOCIALLY DEAD PERSON. Second, taking A JOURNEY BACK to her childhood implies Losses Associated with the Disintegration of the Body. Mende can only feel free inside her mind through imagination. This reflects a sense of imprisonment especially when she realizes that Hanan decides to lock her "in" the house forever. Hence, she loses her autonomy over her own.

Consequently, from the retrieval of the SC as well as the interpretation of the $\mathrm{CM}$ emerge three self-aspects and associated attributes of Mende's self-concept. First, Mende's recall of her ideal self through a SC retrieval implies a temporal self-aspect with two associated attributes: 1) Mende has been identifying herself back in childhood with being a doctor and 2) Mende's very dream of becoming a doctor suggests that she sees herself as an ambitious child who wishes to become the first doctor in a village in the Nuba Mountains. Second, the SC also implies an affective self-aspect as she implicitly feels happy with her father (e.g., " The very thought of those happy, happy times brought tears to my eyes"). Third, the use of the CMs in this example again suggests that Mende conceptualizes herself as a slave in terms of a socially dead person:

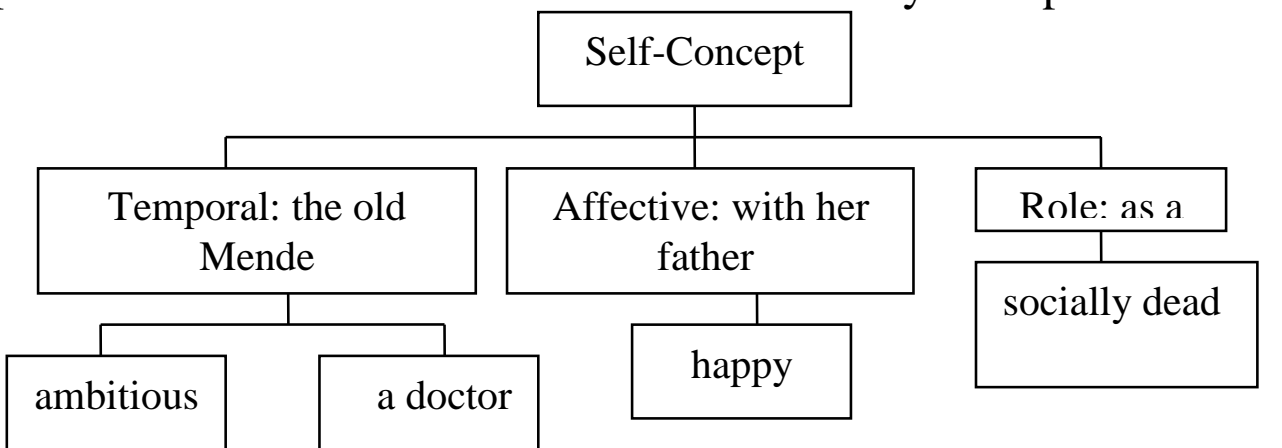

\section{MENDE'S LIFE AS A SLAVE IS A JOURNEY}

Nevertheless, at some point in the narrative, Mende conceptualizes her own slavery experience as a JOURNEY in which she is at a crossroads where she is either to continue being on the SLAVERY JOURNEY or to join in a brand new JOURNEY OF FREEDOM. However, both JOURNEYS are MULTI-STOP consisting of many incidents and states that are conceptualized as DESTINATIONS.

For example, at the end of part three Mende recalls an AF with no accompanying imagery in which Omer helps her to understand her real situation and encourage her to become free. As a result, she conceptualizes herself being in a crossroad where she has to decide which road she will take and which JOURNEY she will join. During spending the family vacation in Sudan, Mr. Koronky and Hanan send Mende to stay with their friend Omer and his wife Madina. Omer now knows 
Mende's true situation that she isn't Hanan's servant and that she is her slave. So, Omer encourages Mende to escape:

The way his family had treated me ... had me realize that I could be human again. And now, Omer had helped me understand that I was a person with rights -- and that people couldn't keep you as a slave in this country. He opened my eyes to my true situation. After talking with him, I decided that I had to try to escape. If I had to go back to my life as a slave, either it would kill me or I would kill myself. Now was my chance, and I had to seize the opportunity before Koronky and Hanan returned. (Nazer \& Lewis, 2003, p.296)

As trying to convince herself and be courageous enough to escape, Mende conceptualizes HER LIFE AS A SLAVE in terms of A JOURNEY that if she chooses to change DIRECTION and get back to it, she would be killed.

Engaging in an AF as a nonimage memory form, Mende gives a set of personal information. Each piece of information, however, corresponds to an instance of CM. First, Mende recalls understanding that she is "a person" and that she can't be a slave anymore. This implies the metaphor MENDE IS AN INDIVIDUAL HUMAN who has "rights." Second, Mende recalls being a knower now. With the help of Omer who has made her understand her "true situation," Mende now knows that she has to be free; she has to escape. In this context, Mende uses the CM of KNOWING IS SEEING. Mende conceptualizes knowing that she is a slave and that she shouldn't stay a slave anymore in terms of SEEING. This, corresponds to the third piece of information in which Mende discovers that she is now a powerful person who decides to "seize the opportunity" to escape before the return of Hanan and her husband from their vacation in Sudan. Again, Mende uses the metaphor THE OPPORTUNITY TO BE FREE IS A TANGIBLE SEEN OBJECT. Conceptualizing her chance to be free in terms of AN OBJECT that can be grabbed implies that it also can be seen. This gives Mende a sense of power; Mende now feels powerful enough to achieve freedom. Finally, conceptualizing herself being again on A CROSSROAD, Mende now knows that if she would change direction and "go back" to join THE SLAVERY JOURNEY, she would end up to A DESTINATION OF BEING DEAD whether through being killed by her masters or through committing suicide.

In addition to that, the metaphor MENDE IS SOCIALLY DEAD can be inferred from the AF and CMs analysis. First, acknowledging that she is a "person with rights" implies A Loss of Social Identity. Admitting that Mende is "a person" suggests that as a slave she considers herself to 
be a subhuman; "something monstrous that exists between the animal and the human." (Noys, 2005:9). Second, conceptualizing SLAVERY in terms of A JOURNEY, Mende conceptualizes THE DESTINATION of such journey in terms of BEING DEAD. This implies that as a slave Mende conceptualizes herself in terms of "homo sacer" in which she is deprived of any legal, social, and cultural protection meaning that she is endangered to be killed at any time by her masters (Králová, 2015; Agamben, 1998).

As a result, four self-aspects with six attributes can be inferred from the analysis so far. Recalling that she acknowledges herself now as a "person" implies that Mende considers her True Self as an individual human. Accordingly, Mende presents her Role as a slave as a subhuman; something other than a human. Moreover, the use of the CMs SLAVERY IS A JOURNEY and BEING DEAD IS A DESTINATION implies Mende's Role as a slave as being homo sacer meaning that staying as a slave means that Mende is exposed of being dead at anytime and by anyone. Additionally, acknowledging now her true situation, Mende conceptualizes her Competence self aspect as a knower and a powerful person who is able to escape and change her destiny. Finally, as a result of identifying herself as a person who has the right to be free as well as a knower and a powerful person, Mende now sets the Goal of becoming free.

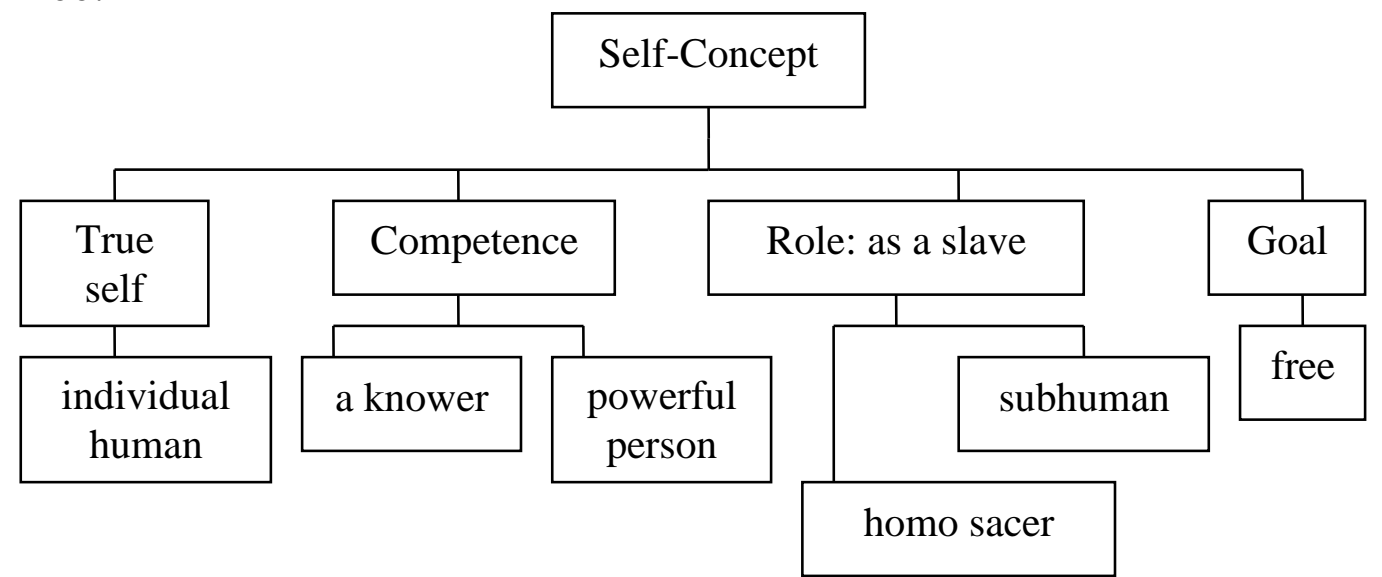

\section{THE PLACE WHERE MENDE EXPERIENCES FREEDOM IS HOME}

The first chapter of part four entitled "Fear of Freedom" begins with the following quote in which Mende recalls an AF about her freedom achieved in London. After having managed to escape with the help of two Nuba men working in London, Mende, first, recalls how she started to identify herself as belonging to a new home. This "new" home is where she has first experienced being free. Thus, using the possessive pronoun of "my," Mende is shifting her sense of belonging from the 
village in the Nuba Mountains (see example 1) to "London." In so doing, Mende conceptualizes THE PLACE WHERE MENDE EXPERIENCES FREEDOM in terms of HOME. At the same time, she conceptualizes FREEDOM in terms of A FOOD TREAT. In this CM, Mende conceptualizes Mende conceptualizes the first time she is free in terms of a first time she tastes a new food. Thus, to Mende, being free is a reward she has been given:

Over the next two years London became my new home and place where I first tasted freedom. How has it been for me? To me freedom is a treasure that I would not give up for all the world. I have realized that those who live in the West often take their freedom for granted. They were born into it and it has always been there for them, and it is their unnoticed, unrecognized, constant companion and friend. But for those of us who come from countries like Sudan, freedom is wonderful and precious. And for those like me who were enslaved, it remains a uniquely beautiful experience (Nazer \& Lewis, 2003, p.311)

Moreover, Mende is engaged with a number of CMs that reflect how she, as a young Sudanese ex-slave woman now, conceptualizes FREEDOM. Mende compares between how the Western communities conceptualize the concept of FREEDOM to how countries like Sudan which suffer from human trafficking conceptualize it. In so doing, she conceptualizes FREEDOM in terms of AN UNNOTICED, ALWAYS THERE CONTAINER, A GOOD FRIEND and PRESCIOUS, UNIQUE TREASURE, respectively. In other words, as opposed to being conceptualized as a reward, a food treat or a unique treasure by Mende as a Sudanese ex-slave woman, FREEDOM is conceptualized as a takenfor-granted object by people living in London. However, Mende's conception of FREEDOM seems to be based on the concept of familiarity. On the one hand, in Mende's viewpoint, the Western people conceptualize FREEDOM as AN UNNOTICED, ALWAYS THERE CONTAINER (e.g., "They were born into it ... "). This implies that the more someone becomes familiar with something, the more it becomes unnoticed and unrecognized. Thus, being born free, the Western communities are always "into" FREEDOM as if they live into it unrecognizing its presence. Moreover, also in Mende's viewpoint, those who live in the West conceptualize FREEDOM in terms of A GOOD COMPANION AND FRIEND. Again, being familiar with FREEDOM, Western people conceptualize it as a person that is always there for them; A TRUE FIREND AND COMPANION. On the other hand, Mende conceptualizes FREEDOM in the view of countries like Sudan in terms of PRESCIOUS, UNIQUE TREASURE. This implies that being unfamiliar 
with FREEDOM, people like Mende conceptualize it as VALUABLE, UNIQUE TREASURE. Hence, the more something becomes unfamiliar, the more it is considered precious.

\section{SLAVERY IS A CONTAINER, FREEDOM IS A TERRIFYING ENTITY, and FREEDOM IS A POSSESSED ENTITY}

Although Mende does manage to escape with the help of two Nuba men working in London, she unconsciously is convinced that she is not free yet; something inside tells her that it is way more difficult than she thinks it is. The title of part four of Slave is a rhetorical question entitled "Truly free?" Throughout part four, Mende is questioning her freedom. Additionally, the very title of the first chapter of part four which is entitled "Fear of Freedom" is echoed in a number of CMs. In the following quote, Mende is engaged in an instance of SC in which she recalls how she has been thinking about herself as a slave. The SC comprises three conceptual metaphors: SLAVERY IS A CONTAINER, FREEDOM IS A TERRIFYING ENTITY, and FREEDOM IS A POSSESSED ENTITY:

But for me, this freedom was also a terrifying thing. I was captured when I was still a child. I spent my teenage years and my early adulthood in slavery. For all that time I had no freedom. I was a non-person. I didn't really exist. (Nazer \& Lewis, 2003, p.311)

In this example, Mende conceptualizes SLAVERY as A CONTAINER. Again, the concept of familiarity is obvious. Being familiar with SLAVERY, Mende speaks of it in terms of A CONTAINER in which she spends her teenage years as well as her early adulthood. However, FREEDOM is conceptualized in terms of two kinds of ENTITY. First, when Mende speaks about being free for the first time in years after escaping from Koronky and Hanan's house, she unconsciously chooses to conceptualize FREEDOM as A TERRIFYING ENTITIY. In so doing, Mende tries to embody freedom as a tangible thing that she gets scared of. Second, when Mende speaks about how she lacks the right of being free, she unconsciously chooses to conceptualize FREEDOM in terms of A POSSESSED ENTITY in which she doesn't have. In both cases, FREEDOM is not a familiar thing to Mende. Moreover, the metaphor MENDE IS SOCIALLY DEAD can be inferred. Recalling that she has thought of herself as not important and not present as is explicitly expressed in the use of the adjectives "non-person" and "non-existent" implies that Mende has been considering herself as socially dead. 
In addition to that, there are yet two self-aspects emerge from the analysis of this example. The title of the fist chapter of part four "Fear of Freedom" as well as the CM FREEDOM IS A TERRIFYING ENTITIY suggest that in a situation where Mende is free again, she conceptualizes herself as being frightened. Also, the recall of the SC where Mende reveals how she used to think about her life when she has been a slave along with the CM MENDE IS SOCIALLY DEAD imply that Mende is socially dead, a "non-person," and "non-existent":

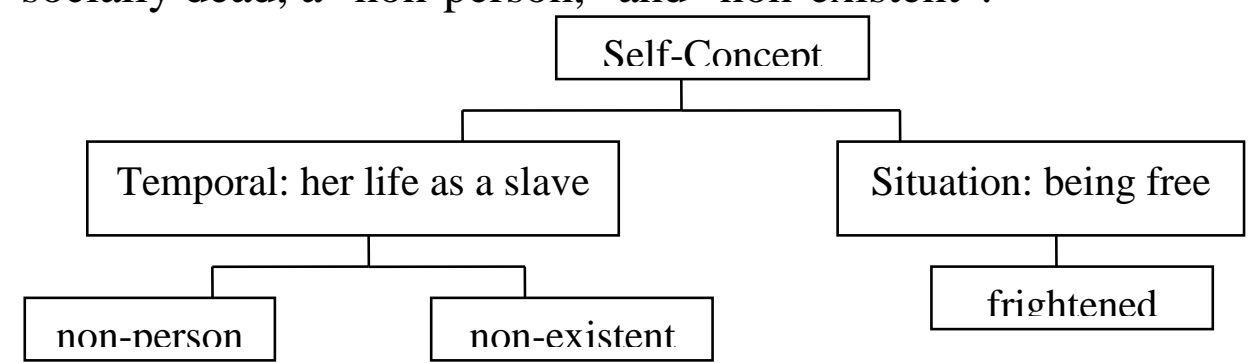

\section{FREEDOM IS A CONTAINER}

Nevertheless, there is one single instance that Mende does actually conceptualize FREEDOM in terms of A CONTAINER; thus, being familiar with it. After re-encountering with her family back in Sudan however only through phone calls, Mende now knows that her parents have been told that she has been converted from Islam to Christianity and that her name has been changed to Caroline. In this context, Mende uses the metaphor FREEDOM IS A CONTAINER:

I explained to my parents that everything they had been told was untrue; that far from being kidnapped in London, I had escaped into freedom; that far from being converted to Christianity, I could now practice my Islamic faith freely for the first time in many years; that far from being in grave danger, I was safer I had ever been during my years of beatings and abuse and enslavement. (Nazer \& Lewis, 2003, p.318)

As it seems, concerning her religious identity, Mende seems not so "frightened," "terrified" nor unfamiliar with FREEDOM anymore. Instead, Mende feels more involved in FREEDOM when it comes to her religious beliefs. As a result, Mende conceptualizes herself "into" A CONTAINER OF FREEDOM. Through conceptualizing FREEDOM in terms of a CONTAINER, Mende depicts herself as a devout Islamic believer. Accordingly, the following self-complexity emerges. Mende is conceptualizing her True Self in terms of a devout Muslim believer: 


\section{Self-Concept \\ True Self: \\ a devout Muslim \\ LIVING AS A SLAVE IS HAVING A NIGHTMARE, MENDE'S UNPLEASANT SLAVERY EXPERIENCE IS A JOURNEY INSIDE A CONTAINER WITH A FAR DESTINATION THAN EXPECTED and FREEDOM IS WAR}

However, there comes a moment where Mende discovers that she hasn't yet reached THE FAR DESTINATIONS OF HER JOURNEYS INSIDE THE SLAVERY CONTAINER. Engaged in an instant of AF where she recalls how she has started a war to sustain being free, Mende uses three instances of CMs: LIVING AS A SLAVE IS HAVING A NIGHTMARE, MENDE'S UNPLEASANT SLAVERY EXPERIENCE IS A JOURNEY INSIDE A CONTAINER WITH A FAR DESTINATION THAN EXPECTED and FREEDOM IS WAR:

So, the nightmare of my years in slavery didn't end as soon as I escaped. It was just the nature of my suffering that changed ... I had to start my fight to remain in England (Nazer \& Lewis, 2003, p.318)

First, Mende conceptualizes her LIFE AS A SLAVE in terms of A FRIGHTENING AND UNPLEASANT DREAM (e.g., "the nightmare of my years in slavery"). The connotation of the word "nightmare" implies being in a frightening and unpleasant situations. These are embedded in the humiliations and the beatings that Mende experiences. Second, Mende conceptualizes THE UNPLEASANT SLAVERY EXPERIENCE in terms of A JOURNEY INSIDE A CONTAINER WITH A FAR DESTINATION THAN EXPECTED. This metaphor implies that FREEDOM IS NOT EASY TO POSSESS nor is it A NEAR-BYDESTINATION JOURNEY. Mende explains this idea through another CM in which she conceptualizes FREEDOM in terms of A WAR. In so doing, Mende is referring to the fact that she has to stay in London to remain free. Actually, after escaping, Mende applies for asylum in the United Kingdom. Mende does this because she knows she can't return back to Sudan; she might get killed mainly for two reasons. First, having escaped, Mende exposes the involvement of the Sudanese government in her slavery. By now Mende has written her first book exposing the role that the regime plays in slavery in Sudan in general. Actually, Mende mentions in her book that when she and the other children have been 
captured back then during the raid, they have been sent to Sudanese government army camps. Second, Mende has been sent to London to be a slave for a Sudanese diplomat. Thus, all of these reasons would jeopardize Mende's freedom. However, applying for asylum in the UK has not been easy for Mende. In this sense Mende conceptualizes FREEDOM in terms of A WAR. Accordingly, another self-aspect with associated attribute emerges:

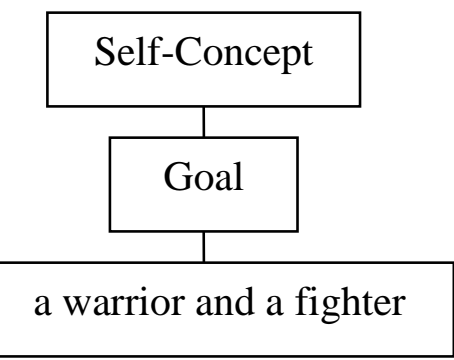

STARTING A NEW FAMILY AND HAVING CHILDREN OF HER OWN IS A ROAD/ HER SENSE OF FAMILY AND IDENTITY IS A DESTINATION

All in all, Mende's JOURNEY TO FREEDOM turns out to be A PSYCHOLOGICAL JOURNEY TO THE SELF; her Self which has been stripped off of her by SLAVERY. In the following example, Mende conceptualizes STARTING A NEW FAMILY AND HAVING CHILDREN OF HER OWN in terms of A ROAD that she must take in order to reach HER SENSE OF FAMILY AND IDENTITY which is conceptualized as A DESTINATION:

A few of my new friends here in London have recently had children, and I am also dreaming about finding a partner and settling down to have a family. For me, that would be one way to rebuild the sense of family, identity and security that my years in slavery and exile have taken from me. (Nazer \& Lewis, 2003, p.334)

Through the use of such metaphor, another self-aspect emerges. Mende in thinking of the future identifies herself with being a mother. It seems that Mende's future JOURNEY TO THE SELF requires her to be a mother herself:

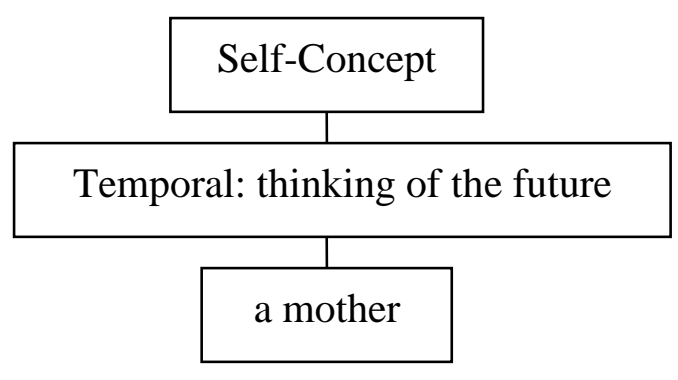




\section{MENDE'S JOURNEY FROM SLAVERY TO FREEDOM IS AN EXPEDITION FOR THE SEARCH OF THE SELF}

Furthermore, this very idea is reassured towards the end of the narrative. In the following quote, Mende conceptualizes her JOURNEY FROM SLAVERY TO FREEDOM in terms of A PSYCHOLOGICAL JOURNEY TO THE SELF or, to put it more precisely, AN EXPEDITION FOR THE SEARCH OF THE SELF:

I still feel my life has a long way to go before it will really make sense to me, before I will really understand where this journey from slavery to freedom is ultimately taking me. And what do I want from life myself? At the moment, I go to school and learn English like any other pupil. But I have no family now and nowhere that feels like home. Where are my roots now? My real identity? My tribe? Am I still a Nuba girl? Or am I a best-selling author? Am I an escaped slave, or an award-winning human rights activist? Am I Sudanese? British? Or just a citizen of the world? I am probably a hybrid of all these things. I am a Muslim woman living in a borrowed London home given me by Jewish friends who live in Switzerland and who read my book in German and reached out me. Should I still take five sugars in my tea, as I always did back in Sudan? Or only one, as my English friends all seem to do? So many uncertainties. So many decisions still to be made. I feel dislocated at times, confused and as if I am still searching ... But ... I am happy ... to follow my heart. (Nazer \& Lewis, 2003, p.334-335)

This example comprises two CMs which contribute in the interpretation of the metaphor MENDE'S JOURNEY FROM SLAVERY TO FREEDOM IS AN EXPEDITION FOR THE SEARCH OF THE SELF. First, Mende conceptualizes her LIFE AS A FREE PERSON in terms of A LONG JOURNEY SHE HASN'T YET REACHED ITS DESTINATION. Now with her appeal for asylum is granted, Mende is given a British travel document. As a result, she is granted her freedom; Mende is now free to go anywhere she likes. She accepts invitations arrived for her from different countries abroad to speak about her slavery experience. However, Mende still doesn't feel totally free. She feels that her LIFE AS A FREE PERSON now has A LONG WAY TO GO before she can reach her desired DESTINATION (e.g., "...my life has a long way to go..."). Second, Mende then asks a number of rhetorical questions all of which are concerned with her life goals, her origin, where she belongs to, or mainly her identity. In so doing, Mende is engaged in two instances of $\mathrm{CM}$ in which she conceptualizes herself in terms of $\mathrm{A}$ 
PLANT. In the first CM, Mende conceptualizes herself as A CUT OFF PLANT with no roots implying that she doesn't feel to belong to a certain place (e.g., "Where are my roots now?" and "I feel dislocated at times"). In the second CM, she conceptualizes herself as A HYBRID PLANT (e.g., "I am probably a hybrid of all these things."). Mende's rhetorical questions suggest that she has a problem identifying herself with the things that make an individual's "real identity." She seems not to know whether she is an author, a Sudanese girl, a Nuba girl who puts five sugars in her tea or an English girl who puts only one. As a result, Mende conceptualizes herself as A HYBRID PLANT suggesting that she might be a mix of different things after all.

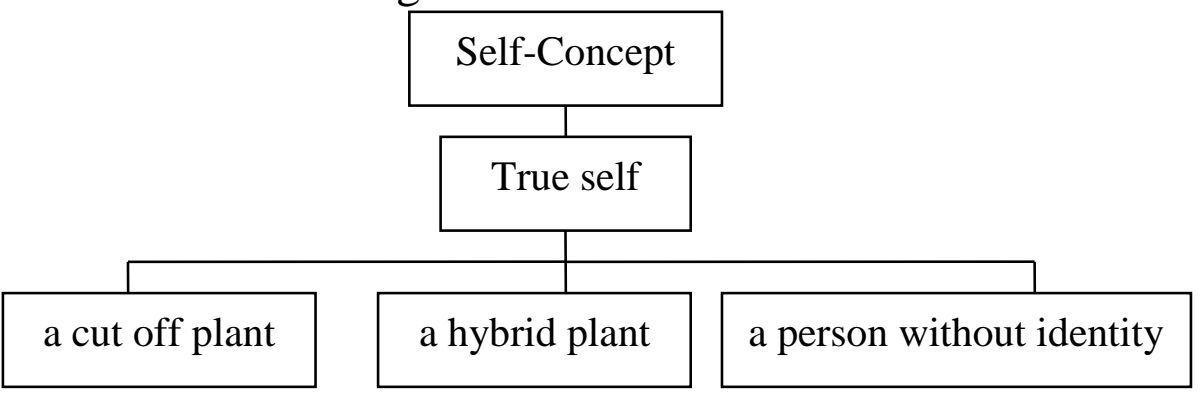

\section{Summary and Conclusion}

This study has investigated conceptual metaphors of slavery and freedom as used by Mende Nazer, an ex-slave Sudanese girl, when writing about her slavery experience. It has been observed that $\mathrm{CM}$ is used as a tool for revealing the protagonist's hidden views about her whole slavery experience, her regaining of freedom, her self-concept as well as her hidden feelings towards her family and her masters. The analysis also reveals that the different autobiographical memory forms help in the unconscious generating of the CMs identified. Moreover, the analysis of both the CM and the memory forms uncover how Mende unconsciously conceptualizes herself as a socially dead person. Finally, the self-concept of the protagonist is identified through the analysis of the $\mathrm{CM}$ of slavery and freedom, autobiographical memory and the application of the notion of social death upon the data.

The main findings of the current study include the following:

1) Both slavery and freedom are talked about in terms of A JOURNEY. However, Mende's FREEDOM JOURNEY turns out to be a psychological one where she changes direction and travels to her home with her family only through remembering.

2) The different autobiographical memory forms are in someway or another held responsible for the unconscious use of CMs of freedom and slavery as well as the unfolding of Mende's self-concept. For example, remembering personal memories, whether single or repeated, with an Observer perspective uncovers Mende's inconsistent multiple 
identities. Additionally, engaging in an autobiographical facts unconsciously generates CMs all of which help in uncovering Mende's self-concept.

3) The notion of social death is inferred through the use of the different CMs relating to the themes of slavery and freedom and the selfconcept emerging. For example, the metaphor MENDE IS SOCIALLY DEAD is inferred from the use of different $\mathrm{CM}$ and the different autobiographical memory. Moreover, Mende's self-aspect of her role as a slave reveals that she self-conceptualizes herself as socially dead, whether through conceptualizing herself as a subhuman, a homo sacer, a nonperson or non-existent.

4) Additionally, Mende's use of the CMs of slavery and freedom helps in the emergence of her true self. Mende's JOURNEYS OF FREEDOM AND SLAVERY unconsciously help her in reaching A DESTINATION. Unfortunately, Mende finds out that her LIFE AS A FREE PERSON now has A LONG WAY TO GO before she can reach her desired DESTINATION (e.g., "...my life has a long way to go..."). This means that she is not a free person after all. Moreover, Mende's final DESTINATION discovers that she suffers from an identity crisis. Towards the end of the narrative, Mende conceptualizes herself as A CUT OFF PLANT and A HYBRID PLANT with no roots implying that she doesn't feel to belong to a certain place. However, when it comes to Mende's religious faith, it seems that she has undoubtedly conceptualizes her true Self in terms of a devout Muslim believer.

5) Similarly, Mende's use of CM within the retrieval of the different autobiographical memory forms helps in uncovering her Relationship self aspect with both her masters and her family and friends. Accordingly, Mende contrasts her self-conception with her master Rahab as being unworthy of care and kindness and invaluable to her selfconception with her family as being worthy of care and kindness and lovable; hence losing her value as a person while being a slave.

6) Moreover, Mende's conceptualizations of SLAVERY in terms of A CONTAINER WITH A FAR DESTINATION THAN EXPECTED and FREEDOM in terms of WAR imply that she has been conceptualizing her Goal in terms of a warrior and a fighter.

7) Another point that uncovers Mende's identity crisis is when she conceptualizes herself as being frightened in the Situation self-aspect of being free. Mende's use of the metaphor FREEDOM IS A TERRIFYING ENTITY within a self-schema about how she has been thinking about herself as a slave implies the irony of conceptualizing herself as terrified 
of freedom; a thing that she has been longing for throughout her slavery journey.

Accordingly, it can be concluded that CM functions as a tool for revealing the hidden meaning and themes of the narrative. This result is in agreement with a number of research (Hernández, 1997). Moreover, the findings reveal that $\mathrm{CM}$ when used in autobiographies, specially in slave narratives, functions as a tool for conveying how the ex-slave conceptualizes both her/his slavery experience as well as her/his regained freedom. Thus, it is consistent with Norman's (1993) study. Consistent with Golden and Lanza (2013), this study also concludes that CM functions as a tool for constructing the narrators' identities and the Self.

Nevertheless, the main contribution of the current study lies in three factors. First, unlike most researchers who treated the Self as a part of the bifurcated person based on the folk theory of the Subject-Self bifurcation (Lakoff, 1992; Lakoff and Johnson's, 1999; Bench et al., 2015; Kenney, 2002; Li, 2011; Hernández, 1997; Harish, 2002; . Arvay et al., 1999), it has treated the Self as emerging from autobiographical memory as a memory of the Self (Brewer, 1986). Second, another aspect that adds to the contribution of this study is that it has considered how the notion of social death - as a defining feature of a master-slave relationship - affects the interpretation of the CMs identified as well as the emerging selfconcept of the protagonist of the narrative. Third, the study also has considered the effects of autobiographical memory forms - as a psychological necessity during autobiographical memory retrieval - on both the interpretation of the CMs identified and the emerging selfconcept unconsciously constructed.

\section{Suggestions for Future Research}

Relying on the present study, the following suggestions for future research are made:

- Studying conceptual metaphors in slave narratives within crosscultural studies

- Studying the effects of autobiographical memory on the use of conceptual metaphors in non-fictional narratives, other than slave narrative, that require memory retrieval acts

- Studying the effects of gender/race as social constructs from a Constructionist approach viewpoint on the use of conceptual metaphors in slave narrative 


\section{References}

Agamben, G. (1998). Homo sacer: Sovereign power and bare life. Stanford, CA: Stanford University Press.

Arikan, S. \& Koçsay, F. G. (2010). Double Alienation In Monica Ali's Novel Brick Lane, E-Journal of New World Sciences Academy Humanitie,(5) 4, 490-505. Retrieved from file:///C:/Users/hp/Downloads/Double_Alienation_in_Monica_Alis_Bri ck_L\%20(1).pdf

Arvay, M., Banister, E., Hoskins, M., \& Snell, A. (1999). Women's Lived Experience of Conceptualizing the Self: Implications for Health Care Practice. Health Care for Women International, 20:363-380. Retrieved from file:///C:/Users/hp/Downloads/073993399245665\%20(1).pdf

Brewer, W.F. (1986). What is Autobiographical Memory? In D.C. Rubin (Ed), Autobiographical Memory (pp. 25-49). Cambridge: Cambridge University Press.

Evans, V. \& Green, M. (2006). Cognitive Linguistics: An Introduction. Edinburgh: Edinburgh University Press.

Friend, E. F. (2012). The Writing Life: Narrative, Metaphor, and Emotion in the Spiritual Autobiographies (Doctoral dissertation). Available from ProQuest Dissertations \& Theses Global database. (Accession Order No. AAT 3525394)

Gecas, V., (1982). The Self-Concept, Annual Reviews,8:1-33. Retrieved from http://www.jstor.org/stable/2945986

Gibbs, R. W. (2008). Metaphor and Thought: The State of the Art, In R. W. Gibbs, Jr. (Ed.), The Cambridge Handbook of Metaphor and Thought (pp.3-16). Cambridge: Cambridge University Press.

Golden, A. and Lanza, E. (2013). Metaphors of culture: Identity construction in migrants' narrative discourse, Intercultural Pragmatics, 10(2): 295-314. DOI 10.1515/ip-2013-0013

Harish, R. (2002). Pen and Needle: The Changing Metaphors of Self in Autobiographies by Women in Post-Independence India. Indian Literature,46(4):161-171. Retrieved from file:///C:/Users/hp/Downloads/23345667\%20(1).pdf

Hernández, L. P. (1997). A Cognitive Analysis of Paul Bowles's The Sheltering Sky. Cuadernosde Filología Inglesa, 3(2):259-278. Retrieved from file:///C:/Users/hp/Downloads/103831.pdf

kövecses. Z, (2010) Metaphor: A Practical Introduction. (2nd ed): Oxford University Press: Oxford.

Králová, J. (2015). What is Social Death?, Contemporary Social Science: Journal of the Academy of Social Sciences, 10(3):235-248. Retrieved from file:///C:/Users/hp/Downloads/RSOC_A_1114407_P\%20(1).pdf

Kromhout, R. and Charles, F. (2013). LIFE IS A JOURNEY: the source-pathgoal schema in the videogames Half-Life, Heavy Rain, and Grim Fandango. Metaphor and the Social World, 3(1): 100-116. Retrieved 
from

https://pure.uva.nl/ws/files/2082263/127260_kromhout_and_Forceville_ 2013_Journey_metaphor_in_videogames_distributed_version_august_2 013.pdf

Kurniawati, Tallapessy, A., and Diana, S. (2014). A Study of Conceptual Metaphor in Suzanne Collins' The Hunger Games. PUBLIKA BUDAYA,3(2):73-77. Retrieved from https://media.neliti.com/media/publications/191224-EN-a-study-ofconceptual-metaphor-in-suzann.pdf

Lakoff, G. and Johnson, M. (1980). Conceptual Metaphors in Everyday Language. The Journal of Philosophy,77(8):453-486. Retrieved from http://www.cse.buffalo.edu/ rapaport/575/F01/lakoff.johnson80.pdf

Lakoff, G. and Johnson, M. (1999). Philosophy in the Flesh. Basic Books: New York.

Lakoff, G. and Johnson, M. (2003). Metaphors we Live by. University of Chicago Press: Chicago.

Leslie, C. (2012). Metaphor, Narrative and Reality in the Life Sciences, Via Panorâmica: An Electronic Journal of Anglo-American Studies, 113131. Retrieved from http://ler.letras.up.pt/uploads/ficheiros/11655.pdf

Li, J. (2011). Verticality, Horizontality, and States of the Self: Cognitive Metaphors for the "Spatial Self" in Chinese Autobiographical Writings. Metaphor and Symbol,26:68-95. Retrieved from file://C:/Users/hp/Downloads/10926488.2011.535418\%20(2).pdf

Martens, G. and Biebuyck, B. (2013). Channelling figurativity through narrative: The paranarrative in fiction and non-fiction, Language and Literature, 22(3): 249-262. DOI: 10.1177/0963947013489242

McConnell, A. R. and Strain, L. M. (2007). Content and Structure of the SelfConcept. In C. Sedikides \& S. Spencer (Eds.), The Self in Social Psychology (pp.51-73). New York: Psychology Press.

McGough, M. Q. (2013). Ending Modern-Day Slavery: Using Research to Inform U.S. Anti-Human Trafficking Efforts. NIJ, 271, 26-32. Retieved from https://www.ncjrs.gov/pdffiles1/nij/240701.pdf

Murphy, L. T. (2014). The New Slave Narrative and the Illegibility of Modern Slavery, Slavery \& Abolition: A Journal of Slave and Post-Slave Studies, 36 (2), pp. 382-405. DOI: 10.1080/0144039X.2014.977528. Retrieved from http://dx.doi.org/10.1080/0144039X.2014.977528

Nazer, M. and Lewis, D. (2003). Slave: My True Story. Public Affairs: New York.

Norman, K. (1993). The Language Of Being And Metaphor Of Autobiography In Frederick Douglass's Narrative, REDEN,6: 21-28. Retrieved fromhttp://dspace.uah.es/dspace/bitstream/handle/10017/4842/The\%20L anguage $\% 20$ of $\% 20$ Being $\% 20$ and $\% 20$ Metaphor $\% 20$ of $\% 20$ Autobiograp hy $\% 20$ in $\% 20$ Frederick\%20Douglass's\%20Narrative.pdf?sequence=1

Noys, B. (2005).The Culture of Death. Oxford: Berg. 
Olney, J. (1985)."I Was Born": Slave Narratives, Their Status as Autobiography and as Literature. In C. T. Davis \& H. L. Gates (Eds), The Slave's Narrative. (pp. 148-174). Oxford: Oxford University Press.

Patterson, H. O. (1982). Slavery and social death: A comparative study. London: Harvard University Press.

Rubin, D. C. (1986). Introduction. In D.C. Rubin (Ed), Autobiographical Memory (pp. 3-16). Cambridge University Press: Cambridge.

Ruth, J. \& Vilkko, A. (1996). Emotions in the Construction of Autobiography. In C. Magai \& S. H. McFadden (Eds) Handbook of Emotion, Adult Development, and Aging, pp. 167-184. San Diego: Academic Press.

Schirrmacher, B. (2017). Disturbing the Metaphor Performance and Medial Presence in the Fiction of Elfriede Jelinek and Günter Grass, Akademisk Kvarter, 16:36-50. Retrieved

from file:///C:/Users/hp/Downloads/DisturbingTheMetaphor_BeateSchirrmac her5.pdf

Seddeek, A. R. and Ehsan, A. (2017). Conceptual Metaphor In The Narrative And Visual Structures Of Suzanne Collins' The Hunger Games, International Journal of Management and Applied Science, 3(2):118130. Retrieved from http://www.worldresearchlibrary.org/up_proc/pdf/562-14853448225062.pdf

Smith, S. and Watson, J. (2005). The Trouble with Autobiography: Cautionary Notes for Narrative Theorists. In J. Phelan \& P. J. Rabinowitz (Eds), A Companion to Narrative Theory. (pp.356-371). Oxford: Blackwell Publishing.

Soloshenko, A. (2016). Emotions in Legal Fiction: Conceptual Metaphors and Cross-Domain Mapping with ATLAS.ti. (Master's Thesis). Available from theses.fr. Retrieved from file:///C:/Users/hp/Downloads/Soloshenko_Alena_2016_ED520.pdf

Talley, J. (2016). Moving from the margins: The role of narrative and metaphor in health literacy. Journal of Communication in Healthcare, 9(2):109119. Retrieved from https://oro.open.ac.uk/46495/1/CIH195_ORO.pdf

Talmantaitö, A. (2008). Conceptual Metaphors Of Death In Tony Morrison's Novel "Sula". (Master's Thesis). Retrieved from file:///C:/Users/hp/Downloads/2001686\%20(1).pdf

Walker, K. (2013). Conceptual Metaphors of Emotion and Narrative Realism in Middlemarch and Anna Karenina (Doctoral dissertation). Retrieved from http://hdl.handle.net/1959.14/337909

Yamina, A. (2016). Analysis of Metaphor in Charles Dickens' Hard Times (Master's Thesis). Retrieved from https://bu.univouargla.dz/master/pdf/Akermi-Yamina.pdf?idmemoire=3976 